\title{
Petr Petrovich Timofeev
}

DOI: $10.3103 / \mathrm{S} 0145875208050098$

Petr Petrovich Timofeev, Professor and the founder of the Department of Lithology and Marine Geology of the Geological Faculty at Moscow State University, Doctor of geological and mineralogical sciences, Corresponding Member of the Russian Academy of Sciences, and Councilor of the Russian Academy of Sciences, died on May 21, 2008. He passed away just half a year before his ninetieth birthday (he was born on November 14, 1918 in Vyaz'ma).

Petr Petrovich was a prominent scientist and a talented organizer of the national science, he devoted his entire life to the solution of fundamental problems of sedimentary geology in general and coal geology in particular. In 1943, he graduated from the Faculty of Geology and Soil Science of Moscow State University and started his professional life in the General Directorate of the Ministry of the Coal Industry of the USSR. Having worked there from 1943 to 1947, he had the opportunity to be involved with many interesting coalfields in the Transcaucasus, the Urals, and in the Kizel basin. In 1947 Petr Petrovich became a post-graduate at the Institute of Geological Sciences of the USSR Academy of Sciences (Geological Institute, Russian Academy of Sciences). All his subsequent scientific activity was associated with this institute. Here he made his way from a post-graduate to the Director of the Institute (1986-1989), the Chairman (1975-1999), and Honorary Chairman (1999-2008) of the Interdepartmental Lithological Committee at the Academy of Sciences.

P. P. Timofeev's teachers were the eminent scientists Yu.A. Zhemchuzhnikov and V.S. Yablokov. Petr Petrovich absorbed their ideas and inventively developed them, having renewed the methodological principles for research of not only coal bearing, but also all the other diverse and uneven-aged sedimentary complexes found both on continents and in oceans. The most major of P.P. Timofeev's achievements was the development and application of two basic methods for investigating the sedimentation process: the method of complex detailed lithological-facies analysis and the method of genetic rock-association analysis of sedimentary and volcanogenic sedimentary successions. Thus, rock associations began to be considered not as parageneses of rocks, but as parageneses of genetic types and facies reflecting historical geological stages in the formation of large paleotectonic structures of the Earth's crust. Most Russian lithologists now use P.P. Timofeev's methodological principles in their everyday practice. He clearly formulated these principles in his doctoral dissertation The Jurassic CoalBearing Rock Association of South Siberia and monographs based on it (1968 and 1970), for which he was awarded the USSR State Prize in 1972. In 1976, he was elected as a Corresponding Member of the Academy of Sciences USSR.

At this point, with the help of his disciples, he began investigating Mesozoic and Cenozoic sedimentation in the Atlantic, studying at the same time sedimentary rock associations in Middle Asia and, later, in the Ciscaucasus and Caucasus. Thus, P.P. Timofeev's range of scientific interests was extremely wide and his scientific production was vast: more than 420 published works, including 15 monographs; 39 candidate's and 25 doctoral dissertations were prepared under his supervision.

At the Moscow State University, P.P. Timofeev's most major achievement was the organization of the Department of Lithology and Marine Geology, which he headed (1983-1989), and, being a professor in the department, he delivered two basic courses "Doctrine of Facies and Paleography" and "Doctrine of Sedimentary Geological Rock Associations" until his final days. Petr Petrovich gave his last examination at this department almost on the eve of his death.

Petr Petrovich was full of creative plans for improving the teaching process and maintaining and developing the genetic aspect of lithological researches in our country. His works were duly recognized. P.P. Timofeev was awarded with the orders of Labor Red Banner, October Revolution, Friendship of Peoples, nine medals, and many diplomas of the Presidium of the Academy of Sciences and the Administration of Moscow State University. His blessed memory will remain forever in the hearts of his pupils and colleagues, and in his scientific works. Faculty administration, Department of Lithology
and Marine Geology, and Editorial Board 